\title{
Correction to: Prevalence of conduct problems and social risk factors in ethnically diverse inner-city schools
}

\author{
Rachel Blakey ${ }^{1,2}$, Craig Morgan ${ }^{1,2^{*}}$, Charlotte Gayer-Anderson ${ }^{1,2}$, Sam Davis ${ }^{1,2}$, Stephanie Beards ${ }^{1}$, \\ Seeromanie Harding ${ }^{3}$, Vanessa Pinfold ${ }^{4}$, Kamaldeep Bhui ${ }^{5}$, Gemma Knowles ${ }^{1,2+}$ and Essi Viding ${ }^{6 \dagger}$
}

\section{Correction to: BMC Public Health 21, 849 (2021)}

https://doi.org/10.1186/s12889-021-10834-5

It was highlighted that in the original article [1] the Acknowledgments section was incomplete. This Correction article shows the correct section. The original article has been updated.

Acknowledgements

We would like to acknowledge all members of our Young Person's advisory group who have contributed throughout the REACH study. We would also like to acknowledge Alexis Karamanos who prepared comparison data from the Millennium Cohort Study. This paper represents independent research in part supported by the ESRC Centre for Society and Mental Health at King's College London (ESRC Reference: ES/S012567/1). The views expressed are those of the author(s) and not necessarily those of the ESRC or King's College London.

\begin{abstract}
of Nutritional Sciences, School of Life Course Sciences, Faculty of Life Sciences \& Medicine, King's College London, Stand WC2R 2LS, UK. ${ }^{4}$ The McPin Foundation, 7-14 Great Dover Street, London SE1 4YR, UK. ${ }^{5}$ Centre for Psychiatry, Wolfson Institute of Preventive Medicine, Barts \& The London, Blakey et al. BMC Public Health (2021) 21:849 Page 12 of 13 Queen Mary University of London, Charterhouse Square Campus, Old Anatomy Building, London EC1M 6BQ, UK. ${ }^{6}$ Developmental Risk and Resilience Unit, University College London, 26 Bedford Way, London WC1H OAP, UK.
\end{abstract}

Published online: 29 November 2021

\section{Reference}

1. Blakey R, et al. Prevalence of conduct problems and social risk factors in ethnically diverse inner-city schools. BMC Public Health. 2021;21:849. https://doi.org/10.1186/s12889-021-10834-5.

\section{Author details}

${ }^{1}$ Health Service and Population Research Department, Institute of Psychiatry, Psychology and Neuroscience, King's College London, London, UK. ${ }^{2}$ ESRC Centre for Society and Mental Health, Institute of Psychiatry, Psychology and Neuroscience, King's College London, London SE5 8AF, UK. ${ }^{3}$ Department

\section{*Correspondence: craig.morgan@kcl.ac.uk}

${ }^{\dagger}$ Gemma Knowles and Essi Viding are joint senior authors.

${ }^{2}$ ESRC Centre for Society and Mental Health, Institute of Psychiatry,

Psychology and Neuroscience, King's College London, London SE5 8AF, UK

Full list of author information is available at the end of the article original author(s) and the source, provide a link to the Creative Commons licence, and indicate if changes were made. The images or other third party material in this article are included in the article's Creative Commons licence, unless indicated otherwise in a credit line to the material. If material is not included in the article's Creative Commons licence and your intended use is not permitted by statutory regulation or exceeds the permitted use, you will need to obtain permission directly from the copyright holder. To view a copy of this licence, visit http://creativecommons.org/licenses/by/4.0/. The Creative Commons Public Domain Dedication waiver (http://creativeco mmons.org/publicdomain/zero/1.0/) applies to the data made available in this article, unless otherwise stated in a credit line to the data. 